\title{
THE SPECTRE OF APARTHEID
}

Nick Shepherd

Anders Gustafsson and Håkan Karlsson deserve our thanks for an exceptionally thoughtful, timely and important paper. They describe the contemporary conjunction between archaeology, cultural heritage and identity politics in Sweden, and a set of disciplinary responses to - as they term it - the "spectre of politics". The first part of the paper describes the embrace of archaeology and cultural heritage by the ultraright, xenophobic, political party Sweden Democrats (SD) as a means of articulating an imagined Swedish identity made up of elements of pure Swedish culture. SD wants to increase the support to "associations, organizations, authorities and institutions that aim at the preservation and stimulation of the Swedish cultural heritage". Like its xenophobic sister party in Denmark, the Danish People's Party, SD has on its agenda the writing of a "cultural canon" that lists "indispensable and significant examples of the Swedish culture. Such a canon could be used as a test of Swedishness, like the obligatory citizenship test and the declaration of loyalty that SD advocates for persons applying for Swedish citizenship, and a way of excluding non-Swedish elements. To an outsider and a non-European like myself, there is something strangely atavistic and backward-looking in the rhetoric of SD. The prohibition on "nonSwedishness", and the notion of a Swedish society consisting of "pure Swedes" practicing a purified culture which reaches back into antiquity - literally into the soil of the motherland - takes us back to the fascism of the I930s and I940s, a case of "back to the future". Closer to home it recalls the ideology of apartheid, similarly predicated on "pure races", "pure cultures" and an organic connection to territory. 
And in many ways this is the point. The current phase of globalisation has turned out to be a paradoxical business, as we are learning to our cost. Economic liberalization and cultural globalization have been accompanied by the (paradoxical) rise of identity politics and the instantiation of significant new barriers and controls to human mobility and human freedom. Xenophobia, Islamophobia, racism, anti-immigrant feeling, and a set of unwelcome threats to the tolerant, humanistic and multicultural societies which have been such an important part of Europe's post-war achievement, must be reckoned as the flip-side of globalisation and as part of a future which looks suddenly threatful. This is a future in which archaeology and cultural heritage assume an unwanted - or at least, problematic-importance (in one of their sharper observations, the authors note that "times of prosperity for archaeology are synonymous with times of unpleasant, xenophobic and/or nationalistic societal and political conditions"). Of course, the conjunction between archaeology, cultural heritage and identity politics is not new; the authors correctly refer to this as the "never-ending story". What is new is that the entanglement of archaeology and cultural heritage with contemporary ultraright groups like SD takes place in the context of increasingly punitive anti-immigration policies in Europe in general, and a re-shaping of the global political order which widens the gap between North and South. Far from being an aberrant situation, particular to fringe developments in Swedish archaeology, it might be argued that Gustafsson and Karlsson's paper points to the future of the discipline as a whole.

What have been the responses from within Swedish archaeology to these alarming developments? The second part of the paper deals with what the authors describe as a state of "low-key trench warfare" which has existed within institutionalized archaeology in Sweden from roughly 2006. As they describe it, the introduction of Agenda Cultural Heritage led to an intensive set of debates in the public media concerning the "role of archaeology, heritage management and cultural heritage in contemporary politics" in 2004-2006. Agenda Cultural Heritage "tried to find a common ground to broaden the content of the concept of cultural heritage, engage the public in the work of cultural heritage, and strengthen a democratic and sustainable societal development and a multicultural society". It also implicitly recognized the socially and politically entangled nature of archaeology and cultural heritage. Those opposed to this programme and to this characterization of disciplinary practice argued on the basis of a theoretical focus on empiricism and cultural history, and a conception of the discipline which sees it taking place distinct from and outside the concerns of contemporary society and politics. The trench warfare ensued when senior (and con- 
servative) scholars used their positions on research councils and granting agencies to divert funds to empirically-focused projects and away from projects focused on a "broader view of cultural heritage and the relationship between archaeology, politics and contemporary society" - including funds which had been earmarked for such purposes. This is another case of "back to the future", since such a conservative framing of archaeological research is reminiscent of the research agendas of the late nineteenth century. In effect this constituted a double blow, in that Swedish archaeology finds itself least able to conduct the kind of robust debate and research around the relationship between archaeology, cultural heritage and contemporary politics at the exact moment when events on a party-political front move to further this entanglement in ways that present us with the spectre of fascism.

Such are the broad outlines of the argument made by Gustafsson and Karlsson, and as I have indicated I regard this as an important argument to be making at this time. A few points by way of commentary: The first is that the argument presented here makes a persuasive case for the position that a characterization of archaeology in terms of empiricism, positivism and a distancing from matters of "society" and "politics", itself constitutes a significant intervention in the politics of practice, of an inherently conservative - even reactionary - nature. In South Africa in the I970s and I980s, such an argument was the standard response presented by those archaeologists who refused critically to engage the politics of apartheid. Here, too, archaeology emerged as the beneficiary of a reactionary political regime. A second point is to underline the importance of the closing formulation from Gustafsson and Karlsson. They write that "there is still time to act and stand up against the xenophobia of this party $[\mathrm{SD}]$ in a defence of a multicultural Swedish society where nobody is denied their human value. Of course, this implies that we do not view the political dimension of archaeology and cultural heritage as a spectre but as creative possibility". Jacques Derrida (1994) has famously re-written Marx, describing "spectres" as that which history has repressed. One of the ironies of archaeology as a discipline has been that it habitually represses its own histories of practice, just as it disavows its contemporary contexts of practice. The feverish dream of positivism, empiricism and an archaeology without politics remains strong in certain sectors. Gustafsson and Karlsson remind us that either we confront the spectres, or we go to work for the brownshirts.

Nick Shepherd Centre for African Studies at the University of Cape Town Rondebosch 7701, South Africa 


\section{REFERENCE}

Derrida, J. I994. Specters of Marx: The State of Debt, the Work of Mourning, and the New International. New York and London: Routledge. 